\title{
Environmental and Occupational Respiratory Diseases - 1031. A study of outdoor aeroallergens in Riyadh, Saudi Arabia
}

\author{
Syed Mohammed Hasnain ${ }^{1 *}$, Salma Kabbara', Abdullah Saad Al-Modaihsh², Othman Mahjob² \\ From 2nd WAO International Scientific Conference (WISC 2012) \\ Hyderabad, India. 6-9 December 2012
}

\section{Background}

To investigate the outdoor aeroallergens at two different, a fully developed (FD) and a less developed (LD), sites in Riyadh, capital city of Saudi Arabia.

\section{Methods}

Two Burkard Volumetric 7-day Recording Spore Traps were employed at both locations. Exposed slides were read at 12 bi-hourly traverses, with a total of 60 fields per 24 hours (0-24hours). The study was initiated in January 2012.

\section{Results}

The data analyzed so far revealed the presence of different pollen and fungal species at both sites. The ratio between the pollen and fungal spores was 1:5. The airborne pollen grains showed quantitative and qualitative differences between the two sites. At FD site, the major pollen grains included Phoenix dactylifera (31\%), grass pollen (14\%), Atriplex nummularia (12\%), Amaranthus viridus (10\%), Artemisia monosperma (7\%), Plantago sp. (6\%) and Populus sp. (4\%). The minor species $(<1 \%)$ were Casuarina sp., Chenopodium murale, Eschscholtzia sp., Eucalyptus sp., Lilium sp., Prosopis juliflora, Salix sp. and Salsola imbricata. At the LD site, the major species included Phoenix dactylifera (36\%), grass pollen (15\%), Salix sp (8\%), Artemisia monosperma (6\%), Atriplex nummularia (6\%), Plantago sp. (3\%), Populus sp. (3\%), Amaranthus viridus (2\%) and Ambrosia sp. (2\%). The minor species included Daucus carota, Eucalyptus sp. and Salsola imbricata. The fungal spores recorded at both sites displayed only quantitative variations. The major components of these spores at

${ }^{1}$ Cell Biology, King Faisal Specialist Hospital and Research Centre, Riyadh, Saudi Arabia

Full list of author information is available at the end of the article
FD site included Arthrinium (14\%), Ulocladium (14\%), Cladosporium (13\%), Alternaria (10\%), ascospore septate (10\%), smut spores (9\%), Basidiospore (7\%), ascospore non septate (6\%), Bipolaris (3\%), Myxomycete (3\%), Periconia (3\%), Aspergillus/Penicillium (2\%), Stemphyllium (2\%) and Curvularia (1\%). The minor components $(<1 \%)$ were Drechslera, Melanospora, Peranospora, Pithomyces and Torula. The major fungal spores at LD site were Ulocladium (13\%), Cladosporium (12\%), Aspergillus/Penicillium (11\%), smut spores (11\%), Alternaria (9\%), ascospore septate (9\%), Basidiospore (9\%), Arthrinium (8\%), Stemphyllium (5\%), ascospore non septate (4\%), Periconia (3\%) and Bipolaris (2\%), while the minor spores included Curvularia, Drechslera, Melanospora, Myxomycete, Peranospora, Pithomyces and Torula.

\section{Conclusions}

The results indicate that developed and less developed sites have no impact on the qualitative and quantitative diversity of fungal spores but such diversities were recorded in airborne pollen species.

\section{Author details}

${ }^{1}$ Cell Biology, King Faisal Specialist Hospital and Research Centre, Riyadh, Saudi Arabia. ${ }^{2}$ College of Agriculture, King Saud University and King Khalid University Hospital, Riyadh, Saudi Arabia.

Published: 23 April 2013

\section{doi:10.1186/1939-4551-6-S1-P30}

Cite this article as: Hasnain et al:: Environmental and Occupational Respiratory Diseases - 1031. A study of outdoor aeroallergens in Riyadh, Saudi Arabia. World Allergy Organization Journal 2013 6(Suppl 1): P30. 